\title{
10. Skywalkers and Cannibals: Chanted Tales among the Angal
}

\author{
Hans Reithofer
}

\section{Preface}

In this chapter I provide a general introduction to the art of chanting tales as practised and valued among Karinj speakers (a West Angal, or Wola, dialect) in the Southern Highlands of Papua New Guinea. Apart from discussing aspects of form and performance as well as content, the social significance of this verbal art and of the stories themselves will be considered in some detail. Why folk tales about skywalkers and cannibals should be important at all—beyond the aesthetic pleasure and entertainment afforded by their skilful performance - is a question that is answered by looking at the influence these stories had on the interpretation and widespread adoption of Christian teachings. As it turned out, Karinj speakers discovered a close correspondence between Christian moral teachings and their own folk tales.

Since this is the only chapter on Angal chanted tales in this volume, I will open with an ethnographic sketch of the wider language area before situating the Karinj speakers within it. This should also help to familiarize non-Melanesianists with the larger sociocultural context. To appreciate the distinctive quality of Karinj chanted tales as compared with other kinds of stories they have, a brief discussion of narrative categories and genres will preface the main section on chanted tales, their properties and significance. The chapter will conclude with some reflections on the current state and possible medium-term development of this verbal art in that area.

It is appropriate to clarify at the outset some aspects of the research context which have affected to some extent the nature as well as some of the limitations of the data and findings presented here. My research on chanted tales among Karinj speakers was not conducted systematically for any appreciable period of time, but instead was a by-product of my research on other topics such as precolonial ritual life and processes of Christianization. The invitation to the second Chanted Tales Workshop in Goroka in 2006 did provide some opportunity for me to follow up on relevant points and collect some more stories, but for a proper research project on this topic I would have needed more time and funds than were available. The majority of chanted tales were related to me by one very gifted narrator, Josep Haip (figure 3), and recorded either at my field house or in houses 
of common friends. Since I worked so extensively with him, or he with me, it is appropriate that he features prominently in this account. Whether chanted or related in prose, almost all of the stories were told or performed because I had signalled my interest in recording (and later transcribing and analysing) them, not because they would have been told anyway at that particular moment. In other words, with very few exceptions I did not hear the stories in their typical social setting, that is, when men or women tell them at night to their various audiences. This has some important implications: I do not know whether performances by women tend to differ from those by men with regard to performance style, choice and composition of stories, exegetical comments, and so forth. Nor can I say how much these variables are determined or influenced by a particular audience and the specific circumstances of a given performance. My data are also too limited for me to be able to differentiate in every instance between standard performance style and individual peculiarities. This would necessitate the analysis of a range of (both male and female) performers.

\section{The Angal language area}

\section{The linguistic situation}

As the linguistic situation is potentially confusing, it seems best to begin here, even though the reader should not expect language borders to coincide with sociocultural boundaries - a point that will be argued shortly. The Angal language group, ${ }^{1}$ variously subsumed under other umbrella terms such as Wola and Mendi, comprises about 80,000 speakers (Gordon 2005) occupying five valleys in the Southern Highlands Province of Papua New Guinea that are drained by the following rivers (from east to west): the Mendi, Lai, Nembi, Was (or Wage), and Ak (or Augu). For the three main Angal "languages," their approximate numbers of speakers and boundaries, see figure 1 in this chapter and figure 2 in chapter 1. The principal terms given to the "languages" (in bold italics in figure 1 here) may each be translated as 'the normal language' or 'the true talk', since angal means 'word, talk, language' and the cognate terms heneng, enen,

\footnotetext{
1 See chapter 1 for details and references on the classification of Angal languages within the Engan group of the Trans New Guinea family.

2 Although Ethnologue (Gordon 2005) treats the three members of the Angal group as separate languages, the question whether they are to be classified as dialects rather than languages remains as unanswered as it was forty-five years ago (Rule 1965:98). This has certainly to do with the fact that, apart from one rather preliminary paper (Rule 1965) and one linguistic study on Nembi narrative and procedural discourse (Tipton 1982), no academic analyses of any of the three Angal languages have been published so far. The main "dialects" are quite distinct, but only to some extent mutually unintelligible. It appears that communication is most difficult (but not impossible) between the western and southern "dialects" (Schlatter, pers. comm., 29 April 1999; Sillitoe 1979a:13 n. 8).
} 
and henen 'true' or 'real' or just 'normal, everyday, standard'. ${ }^{3}$ Figure 1 also lists Karinj (sometimes spelled Katinja in accordance with Enga orthography), a dialect variant of (West) Angal Heneng or Wola spoken in the northwest corner of the language area. That area and its inhabitants are the main ethnographic focus of this chapter.

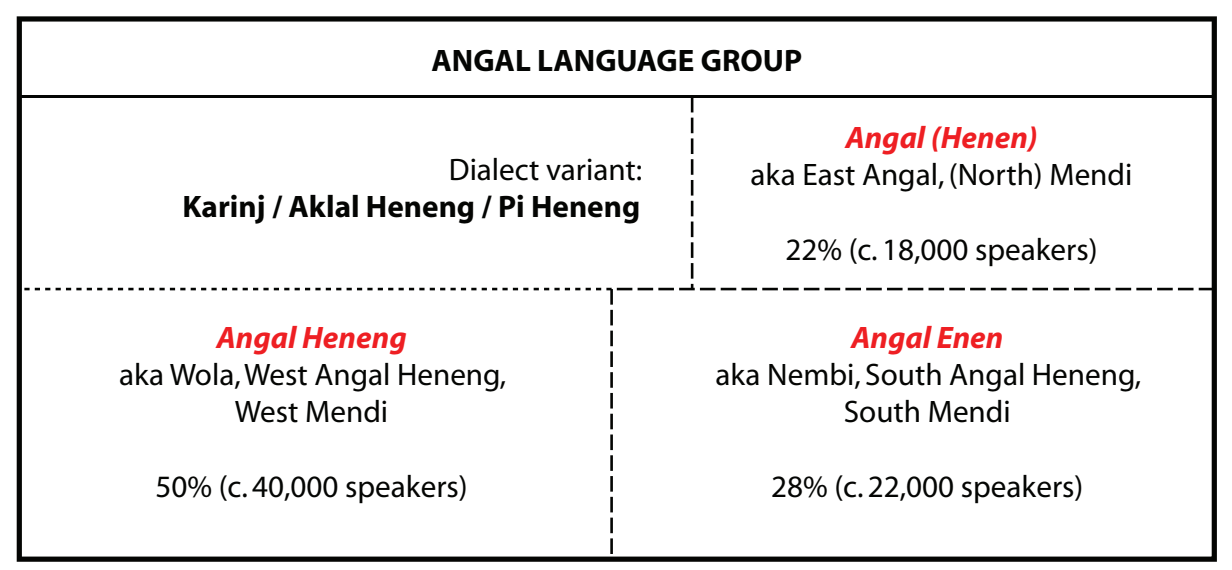

Figure 1. The Angal language group, based on Gordon (2005) and Vic Schlatter (pers. comm., 29 Apr 1999).

The term karinj may be rendered as 'west' or 'western'4 and is a term with shifting referents within the Angal language area. The Mendi in the east would call the West Angal area and its inhabitants Karinj, while the Karinj speakers I worked with, in turn, reserved the term for the people and area to their west, that is, to the Wage valley and its population around Margarima. Karinj speakers refer to their specific dialect as Aklal Heneng (in distinction to Angal Heneng) or-more often - as Pi Heneng (again 'the true/normal language'), a term that already indicates the influence from, and proximity to, Enga ( $p i i=$ Enga for 'word/talk') and Huli ( $b i=$ 'word/talk').

Although Angal speakers of all shades would certainly acknowledge the relatedness of their respective languages, ${ }^{5}$ ethnographers caution against the assumption of sociocultural homogeneity on linguistic grounds (e.g., Lederman 1986a:8-9; Sillitoe 1979a:24-30). Studies from different parts of the language area (Sillitoe 1979a; Lederman 1986a; Nihill 1996; Reithofer 2006) provide

3 Theodore Mawe, a Mendi (East Angal) speaker, offered another etymology at the 2006 Goroka workshop: translating enen as 'lower' in the sense of downriver or lower altitude, Angal Enen could rather be rendered as the 'Lower Language'. The anthropologist Michael Nihill used the term Anganen for the people of the Lower Lai and Nembi Rivers and accounted for it in yet another way_as 'talk' (anga) of this 'general region' (nene) (Nihill 1999:70).

4 In Angal, the term karinj is used, together with its counterpart aron, to refer to opposite sides of a valley; given the general north-south-flow of the main rivers, these terms thus denote 'west' and 'east', respectively (cf. Sillitoe 1979a:26-28).

5 See Nihill (1999:84 n. 7) for a Lower Nembi perspective on this linguistic commonality. 
enough evidence to conclude that there is as much exchange, borrowing, and mutual influence with speakers of other languages as between Angal-speaking groups themselves, giving rise to an internal heterogeneity that manifests itself in various domains of the social, economic, political, and religious life (e.g., land tenure, leadership, marriage, exchange, ritual). ${ }^{6}$ Linguistic boundaries, in other words, matter little, and commonalities may be greater between groups with adjoining territories and different languages than between widely spaced groups of the same or closely related language. This should be kept in mind for the following sociocultural notes. The intention is to point out some relevant features of the language area, not to suggest a sharply bounded cultural region.

\section{Ethnographic sketch}

Much of the Angal language area is limestone country characterized by heavily forested mountain ridges and roaring rivers, on the one hand, and neatly patterned gardens and extensive cane grassland in the settled parts, on the other. The entire area is divided in territories associated with larger kin-founded groups variously rendered as clans, clan clusters, tribes, or clan/tribal alliances in the ethnographic literature. ${ }^{7}$ These larger territorial groups are invariably divided into smaller localized kin-based groups that have an agnatic bias (i.e., exhibit a preference for membership following the male line), both in practice and in ideology (Sillitoe 1999:336-37). Notwithstanding this patrilineal preference, these smaller local communities living in more or less scattered settlements are very much bilaterally constituted, and all researchers stress the absence of discrimination against people who have joined the group on the basis of other (kin) connections - for example, through their mother or wife. By virtue of the blood ties between their members, local groups are usually and ideally exogamous (i.e., strictly out-marrying). This requirement of exogamy, in conjunction with the fact that most married women live with their husband's group rather than their own, is clearly mirrored in the standard plots of chanted stories in Angal. Each "clan" territory contains one or more ceremonial grounds, the centre of social and political life. These carefully levelled and cleared areas surrounded by tall casuarinas (Casuarina oligodon)

\footnotetext{
6 A number of recent volumes in the comparative vein (A. Strathern and Stürzenhofecker 1994; Biersack 1995a; Goldman and Ballard 1998; Ballard and Clark 1999; A. Strathern and Stewart 2000) have shown that this pattern of intense intercommunication and interdependence through history and across "cultures," linguistic and physical boundaries applies to the broader western Highlands region of Papua New Guinea more generally.

7 The terms are problematic for suggesting a social organization heavily premised on unilineal (in this case, patrilineal) descent, giving rise to patrilineal descent groups and descent-based political corporations that are both inappropriate to capture the socio-political realities of the Highlands region more generally. But this is not the place to broach this rather large debate; see Sillitoe (e.g., 1979a:30-33, 1999) for a critical discussion from a Wola (West Angal) perspective. The terms are appropriate, however, for reflecting the descent ideology that pervades people's representations of the structure and solidarity of their groups (A. Strathern 1968; Lederman 1986a:19-61), and it is in this sense that I use these terms.
} 
have a park-like appearance and set the stage for dances and pig-feasts, general meetings and chatting. Scenes of a pig-kill and a dance are almost a required part of every chanted tale, as we shall see.

The Angal are largely swidden agriculturalists, cultivating sites within an altitudinal range from 1,300 to 2,600 metres. The staple is sweet potato, supplemented by crops such as bananas, various cucurbits, greens and beans, sugar-cane, and taro. Coffee has gained importance in recent years as a cash crop, notably in eastern and southern parts of the area. Like other Highlanders, the Angal keep pig herds of considerable size, which they channel into an extensive exchange system, a point I will return to presently. Hunting (mainly of marsupials, cassowaries, and other birds) is culturally valued, but does not contribute to the daily diet in any significant way (Sillitoe 2003). This contrasts with the hunting as portrayed in many stories, a possible reflection of older subsistence strategies in which hunting may have complemented agriculture to a greater extent (but see Sillitoe 2002). As elsewhere in the Highlands, subsistence activities are strongly gendered, with men being responsible for the heavy work of clearing and fencing garden land and claiming hunting as their domain, while women assume largely the tasks of routine cultivation and harvesting as well as pig-rearing.

All Angal communities have elaborate systems of exchange, both in the form of everyday and comparatively small-scale exchanges carried out between individuals or families, and in the form of large-scale public events sponsored by local groups. It is certainly not merely a reflection of the prevailing zeitgeist that anthropological research in all three Angal "language communities" has produced monographs focused on exchange (Ryan 1961; Sillitoe 1979a; Lederman 1986a; Nihill 1986). Large public exchanges in the contexts of warfare reparation payments and pig-killing festivals are the more prestigious and conspicuous events; the latter may culminate in massive pig kills involving up to 2,000 pigs killed within a few days and pork distributed to thousands of people, as has been reported for the mok ink festival of the Mendi area (Ryan 1961; Lederman 1986a). It is the everyday form of exchange, however, that is the backbone of Angal social life. Constituting an interminable series of exchanges notably in the contexts of marriage and death, it involves more transactors and more (kinds of) wealth than its more conspicuous counterpart: pigs and pearlshells in the past, along with other sea shells, tigaso decorating oil from the Kutubu region and other valuables, nowadays mostly pigs and cash. These quotidian and multiple exchange transactions create and sustain durable relations between individuals of different local groups, most often between affines (in-laws). Everyday exchange thus fosters extra-group ties and challenges intra-group solidarity, but without these personal networks of exchange partnerships, large-scale exchange 
displays foregrounding the group would be all but impossible. In social practice, the two forms of exchange are indissolubly linked, both hierarchically and complementarily (see, especially, Lederman 1986a, 1990).

The staging of pig-kills, a standard theme of chanted tales, was done not only in the context of large-scale public prestations. While the history of ceremonial pig-killing festivals such as the mok ink of the Mendi may be less than a century long, major pig-kills with a probably longer history were held in association with a number of fertility cults (Mawe 1982; Lederman 1986a:181-82; Nihill 1996). Invariably controlled by men, these fertility cults were concerned with the continued or improved reproduction of people, pigs, and the land. Female participation in these cults, even as spectators, was severely limited. But even most of these cults were not simply autochthonous to the area but imported from other groups and subsequently adapted and also transmitted to others, much in the same way as other trade items (such as shells, oil, axes and adzes, pigs, salt, fur and feathers, drums, bows, and so on) as well as stories and beliefs were circulated along the trading routes that criss-crossed language borders and physical boundaries (e.g., Crittenden 1991). A famous case in point is the Timp (or Rimbu) fertility cult: while it attracted much colonial attention in the then Southern Highlands District when it swept like a bushfire through the Mendi area in the 1950s and 1960s, it had been adopted from southern Angal speakers in the Lower Lai and Nembi valleys who, in turn, had been introduced to it by their trading partners to the south some fifty years earlier (Lederman 1986a; Nihill 1996:277).

While participation in these fertility cults cut across "clan" lines, thus emphasizing — according to some researchers (e.g., Lederman 1986a:58-59) the importance of a general male solidarity over "clan" solidarity, there is also evidence of a patrilineal ancestral cult of longer standing which was inwardly oriented, concerned with preserving the viability and strength of local kinbased groups (A. Strathern 1994:240; Wiessner and Tumu 1998:199; Reithofer 2006:122-33). Ritual practices involved the handling of sacred stones and the occasional sacrifice of a pig to ancestral spirits believed to cause sickness and death, on the one hand, and to confer blessing and assistance on their living descendants, on the other. Both basic templates of cults were practised in a bewildering array of local and regional variants until Christian missionization, which for most parts of the language area began in the 1960s - except for the Mendi area proper, where the Methodist Overseas Mission founded a station in 1950 .

Another common feature salient to a large group of sung stories involving a cannibal ogre is related to the fact that the Angal area, as part of the Highlands region, borders on the Papuan lowlands inhabited by groups with markedly different languages and customs. The social universe of Angal groups is thus 
more heterogeneous than that of more central Highland communities, and there is a prevailing image of the south as feared and dangerous (Nihill 1999:75), populated by powerful sorcerers and cannibals. The malarial climate of the lowland forests certainly contributed to this perception (Crittenden 1991:135-37). This did not prevent southern Angal groups from sustaining trading relationships with these groups, even to the point of hiring sorcerers or purchasing sorcery techniques for their own use, but they always did so with caution (Crittenden 1991:136; Sillitoe 1979b:42-43). The same perception of the south also obtained among the northernmost Angal communities, the Karinj speakers, and proved a rich inspirational source for their popular cannibal stories.

\section{The Karinj and the Somaip "tribe"}

The Karinj-speaking groups occupy the high country of the upper Wage and Lai Rivers of the Enga and Southern Highlands Provinces. From the Wage, the land rises sharply into a folded range of mountains reaching over 3,000 metres, but gives way to a series of foothills and rolling grassland as it descends towards the swamps of the Lai valley. Virtually all of the land lies above 2,300 metres. Both culturally and linguistically, this is a transitional zone. Three major languages intersect here: Enga, Huli, and Angal (in the Karinj dialect). The larger territorial groups or "tribes" that live here (such as the Timitopa, Yalipuni, and Maulu) ${ }^{8}$ reflect this border situation as they typically comprise not only Karinj but also Enga- and/or Huli-speaking groups - the result of migration, dispersal, and a wide variety of exchange networks across language boundaries. Not surprisingly, many Karinj individuals are bilingual, and not a few trilingual.

This applies also to the one Karinj "tribe" with which I have worked more specifically: the Somaip, known as Yamape in Enga and Yamabu in Huli. Notwithstanding the linguistic diversity existing among them, their sense of tribal unity and identity is securely anchored in their origin myth and was regularly reinforced - in pre-Christian times - by cult performances in which representatives of all Somaip "clans" participated to appease the "Python Spirit," their founding ancestor, in order to renew the world. The same cult also had a strong centrifugal dimension, as it was performed at a site the Somaip viewed as the centre of a wide-reaching ritual network connecting them to the Huli, Ipili, and Enga. ${ }^{9}$ This illustrates the point made above: the Somaip's primary allegiances were with neighbouring Enga- and Huli-speaking groups to their north and west,

8 I use here the Enga orthographic transcriptions (cf. Wiessner and Tumu 1998); the Karinj pronounce the names more like Timorop, Salupisi, and Maul.

9 See Reithofer (2006:163-77) for a detailed discussion of this Tunda cult, known as Tondaka by the Enga and Tuandaga by the Huli. 
rather than with other Angal speakers to their south and southeast. They also vigorously opposed the aforementioned Timp fertility cult as incompatible with their own ritual practices and halted its rapid spread at their territorial borders.

As keepers of what they regarded as the world's ultimate sacred site, the Somaip perceived themselves as being at the ritual hub of a multi-ethnic universe. Their self-description as the world's 'centre-people' (hoinyal el) was also explicated in linguistic terms: "We live right in the middle, where three big languages converge which we can understand, while we also have our own local language [i.e., Karinj]." Like other Karinj “tribes," the Somaip were, in pre-colonial times, acutely aware of the many differences existing between the various groups in terms of language, dress, customs, etc. Yet they also shared the sense of an underlying, fundamental commonality that was mythologically grounded in the figure of Hela, the "father of all people" - of all people, that is, that were considered 'true humans' (ol heneng). Hela gave birth to Hela-Hul (the Huli), Hela-Tuna (the Duna), Hela-Tukupa (comprising groups west and south of the Tari Basin), and Hela-Open (comprising the Wola, Karinj, and Enga). ${ }^{10}$ This social universe, which relegated the feared populations in the far south to a periphery outside "true humanity," was expressed in various ways in the chanted tales, as we will see.

\section{Enj: Chanted tales among the Karinj}

\section{Genres of story}

Karinj speakers make a basic distinction between narrative and non-narrative discourse by referring to the former as enj (story, tale) and to the latter as pi (word, talk). Within the narrative domain, the Somaip recognize, as do other Karinj speakers, several categories, which may be labelled as enj or arman or a combination of both-enj-arman. But the categorizations are in fact quite fluid as there are at least two cross-cutting axes of distinction that may be employed. Consequently, the labels too vary in their meaning (see figure 2 for a summary of this argument).

One axis of distinction emphasized by the Somaip men with whom I discussed the matter in the run-up to the 2006 Goroka workshop, focuses on the historical, social, and political relevance of stories and leads to the basic distinction between rather irrelevant 'fiction' (enj) and more significant 'history' (arman). From this perspective, the two categories may encompass the following types of narratives:

10 Again, this is an idea that connects the Karinj to the Huli, Duna, and Ipili to their west, who entertain very similar ideas about a mythical father figure of "all people" (cf. Frankel 1986; Ballard 1994; Biersack 1995b), rather than to other Angal speakers, who do not seem to hold such a notion (Sillitoe, pers. comm., 25 April 2008). 
Enj as 'fiction' may be translated as 'folk tales' and refers to the sung stories this chapter (and volume) is concerned with.

Arman as 'history' comprises narratives that 'have a base' (te hai), that is, a grounding in reality. Among them:

- Origin myths of social groups (such as the Somaip "tribe") and cult practices: Despite their fantastic elements and primordial settings, these "myths" belong to the historical arman-category, it was argued, because they were not just enj or Tok Pisin stori nating ('mere stories') but "true stories - our history." 11 These origin myths thus stand in a hierarchical relationship to chanted tales or enj. They are "emplaced" in the local or regional landscape and record the deeds of primordial ancestors who have shaped this very landscape (cf. Rumsey and Weiner 2001). Only the people whose history is recorded in these origin myths will really know them, that is, in their details, hidden meanings, and the like. Regarded as important and also potent stories/knowledge, they are not readily disclosed to outsiders; when I was told them, it was typically with considerable reluctance and secrecy.

- Genealogies: While most Karinj speakers do not use a specific genre to recite genealogies, these are certainly considered important as individual "historical" knowledge and hence arman, even though they typically extend back into mythical origin times.

- Remembered history: Stories relating events of a more recent or "historical" past as they involve persons that can be firmly placed genealogically. These may concern outstanding exchange events, cult performances, warfare, extraordinary feats of men of renown, famines, and the like. ${ }^{12}$

- News or stories from other places concerning supposedly true incidents (also referred to as tema).

Another type of narrative may be called fables or etiological stories, as they explain, for instance, the contrasting "lifestyles" of flea and cockroach. Initially classified as arman because they were "true," they were then placed in the enj category and finally slotted in between as enj-arman, a further indication of the fluid nature of story categorization.

Following another axis of distinction based on formal criteria of performance, enj are those stories delivered in a distinctive melodic recitation style, while arman are those presented in relatively unembellished prose. From this

\footnotetext{
11 In line with the general argument of fluid story categorizations, the neighbouring Wola use the term injiy (=enj) in reference to such origin stories: ol maerizor injiy (lit., 'man borne story') (Sillitoe 1999:336). They also often refer to stories more generally as injiyatmaen (= enj + arman), thus conflating the two labels and abrogating a categoric distinction between the two (Sillitoe, pers. comm., 25 April 2008).

12 A good discussion of Mendi "historical" story genres and historical consciousness more generally is provided by Lederman (1986b).
} 
perspective, different narrative genres may be either categorized as enj or as arman, depending on the performance, as illustrated by figure 2 . While it is true that the only stories typically chanted are folk tales, the boundaries become blurred, once again, for various reasons. First, gifted storytellers often employ elements of enj-performances (clearly demarcated lines, line-final vowels or vocables) when relating origin stories of their own or other social groups. One remarkable Karinj performer, Josep Haip, claims that he can perform any story in enj-fashion. Second, arman origin stories also share many elements with enj folk tales: certain themes and motifs, such as elaborate dress-up and decoration before taking off for a journey, marvellous pig-kills, things or persons disguising their true nature or character. Third, even the most paradigmatic folk tales are often told in prose, and would then be described as being told 'just so, in armanstyle' (pahame arman was).

\section{Narrative vs. non-narrative discourse:}

\begin{tabular}{l|l} 
Narrative genres: & $\boldsymbol{e} \boldsymbol{j} \mathbf{j}=$ story (generic term) \\
\hline Non-narrative genres: & $\boldsymbol{p i}=$ talk (generic term)
\end{tabular}

\section{Historical/social/political relevance:}

\begin{tabular}{|c|c|}
\hline Least relevant: & enj = "fiction" (folk tales) \\
\hline True, but of little relevance: & enj-arman = fables, etiological stories \\
\hline Most relevant: & $\begin{array}{l}\text { arman: } \\
\text { 1. origin myths/stories of clans, tribes, cults, etc. } \\
\text { 2. genealogies } \\
\text { 3. accounts of historical and contemporary events } \\
\text { 4. biblical stories }\end{array}$ \\
\hline
\end{tabular}

\section{Performance style:}

\begin{tabular}{l|l} 
& enj: \\
Distinctive melodic style & 1. folk tales \\
(chanted/sung): & 2. fables, etiological stories \\
& 3. origin myths/stories of clans, tribes, cults, etc. \\
& 4. biblical stories \\
\hline & $\begin{array}{l}\text { arman: } \\
\text { 1. folk tales }\end{array}$ \\
& 2. fables, etiological stories \\
Narrated in prose: & $\begin{array}{l}\text { 3. origin myths/stories of clans, tribes, cults, etc. } \\
\text { 5. accounts of historical and contemporary events }\end{array}$ \\
& 6. biblical stories
\end{tabular}

Figure 2. Karinj narrative terms and distinctions according to different criteria. 


\section{The social significance of enj folk tales}

The etymology of the term enj is unclear. Questions in this regard were met with shrugs. ${ }^{13}$ The term is possibly related to the far past tense of the verb la (speak/tell): inja; both the verb and the tense are prevalent in sung stories. If the suggestion has some merit-Somaip friends neither denied nor affirmed itthe term would encapsulate the general knowledge and expectation that chanted tales are "stories from a distant past."

Enj folk tales are primarily told for entertainment (turi te: to make people 'feel happy'), but also-according to catechist Alois Along (Goroka Workshop 2006) - to let listeners settle down from a sad or turbulent experience or gain a new perspective on their current life situation. Most stories contain fairly explicit moral messages which may be further explicated in exegetical commentaries proffered by performers as a kind of postscript at least in some instances. ${ }^{14}$ The morals of folk tales (discussed in the following section) point to an educational aspect and potential of enj storytelling and make it appropriate to view the verbal art as a form of "edutainment." Entertainment is the dominant factor, though, and it is for this reason that enj storytelling is so much more appreciated when delivered in a rather definite melodic style, which is typically done indoors at night. ${ }^{15}$ The reputation enjoyed by accomplished performers is correspondingly high, not least because there are few who acquire this special skill which takes a good deal of time and dedication to train and develop. Josep Haip (figure 3) is such a specialist. A man in his fifties when we met in 1998, he was widely known for his performance skills which he had learned from various local bards over long years of exercise in his teens. The art of singing stories had fascinated him since his childhood days. Without this strong interest, he said, it would be impossible to persevere and become a master bard. In the course of his career, Haip had created his own distinctive performance style and commanded a seemingly inexhaustible pool of stories and episodes to draw upon. Performers like him expect (or demand) some sort of payment that commonly consists of tobacco, some money, or a drink in appreciation of their strenuous performance (said to cause backache and a dry throat) and their demonstrated skill as entertainers captivating their audience. Like other bards, Haip has on occasion been hired

13 Theodore Mawe at the 2006 Chanted Tales Workshop pointed out that the cognate Mendi (East Angal) term inj refers also to a leech and suggested this as an etymology. The same homology applies to the term enj, but my Karinj interlocutors viewed this as a coincidence, without any etymological import.

14 As noted earlier, my data are insufficient in this regard. Narrators sometimes added commentaries after relating a story to me without any prompting, but they possibly did so in anticipation of curious questions I usually asked in such situations.

15 Whether told in prose or chanted, the basic verb la ('speak/tell') is used for the act of delivering an enjand any other story genres, speeches and talk, for that matter. By adding certain conjunctions or adjectives, however, one can express the fact that an enj-story was chanted 'in style' (mo hain) or told 'just so' (pahame); but neither of these expressions is exclusive to the semantic domain of enj. One can also build a house or deliver a speech 'in style'. 
also by political candidates to perform in the context of their campaigns in order to make their voters "feel happy." In such cases, the enlisted narrator expects a payment of a suitably higher amount of money. While both men and women may chant enj, there are more male than female performers known in the region. ${ }^{16}$

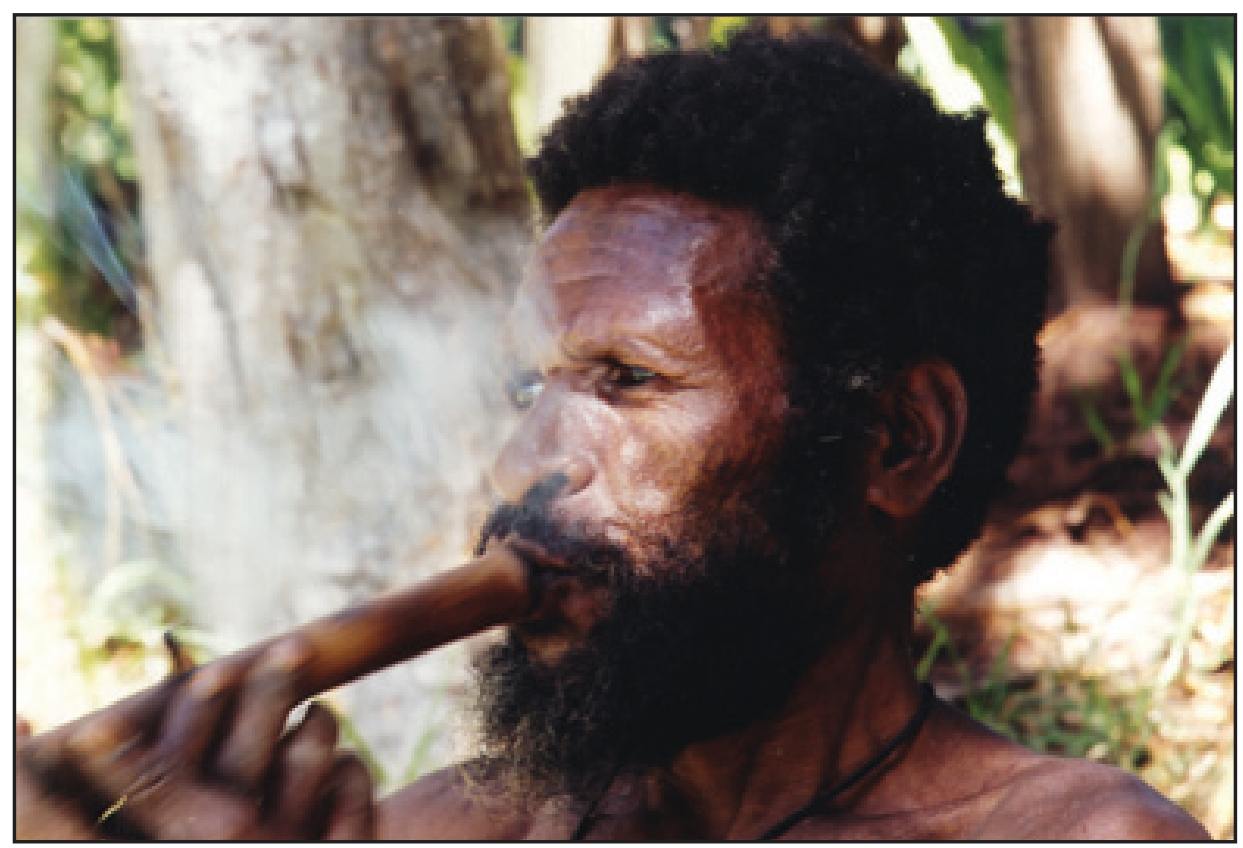

Figure 3. Narrator Josep Haip enjoying a smoke on his pipe, August 1998 (photo by author).

Since anyone-men, women, or children-may hear these stories, the actual audience will depend primarily on the type of house in which a story is performed (men's houses, women's or family houses, nowadays also churchrelated community houses) and on the overall context (such as a singsing or a political campaign). Through extensive use of parallel repetition and synonym substitutions, and the insertion — or omission — of stock episodes, performances using the "same" story plot may vary greatly in length and span several hours. One performance by Josep Haip lasted well over two hours, interrupted by a meal that was part of his payment. He claimed that he could have made it last much longer.

A novel performance type is the enactment of folk tales (and other stories) on public occasions, such as church feasts and school-sponsored cultural days. I have witnessed — and unwittingly facilitated - Karinj enactments of enj folk tales

16 I have never attended a woman's enj-performance nor inquired whether stories told by women tended to be more educational than those told by men, as has been pointed out at the 2006 Goroka workshop for the Duna, for instance. 
on two occasions when I sponsored a communal day of sports and performances at Ipisam, my fieldwork base. Not surprisingly, it was Josep Haip who persuaded his group to enact a popular folk tale featuring the cannibal figure Wan Heyo (figures 4-5) on the first occasion in 2000. While he assumed the role of the narrator, he presented the storyline in prose and as a kind of running commentary to the enactment. The innovation extended also to the interpretation of the story, as discussed in the section on Christianization below. The audience liked it, and there were more such performances years later on the second occasion. Such enactments of popular stories and pre-Christian ritual performances are known to the Karinj through various other contexts in which the representation and celebration of one's cultural traditions are encouraged. Aside from school and church festivities, the most prominent ones are state-sponsored events, such as cultural shows and Independence Day celebrations.

As is common throughout the region, enj folk tales do not have individual authors. There is a pool of stories from which any performer might draw and to which he or she may add new ones from other regions. Variations between different performers concerning the "same" story pose no problem. The standard reply to queries about variations is also a typical expression of valued individuality: "That's how he or she has heard the story, and that's how I have heard it. That's all." Many of the stories are widely known within a given region, but there are no definite "titles" associated with them. If a particular story is requested from a listener, he or she would summarize the most typical features of it in a few words or refer to the predominant protagonist and say something, such as, "tell us about what so-and-so did long ago."

My Karinj interlocutors claim that the art of performing enj in style is restricted to their area and does not extend to other areas like Nipa or Mendi. (They are aware, however, of equivalents among the Huli-bi te-and Enga-tindi pii.) This claim bespeaks some ethnocentric pride but does not entirely hold up against other evidence. Ruth Tipton collected several 'ancestral stories' or inji during her linguistic research on the Nembi Plateau and in the Nipa area in the early 1970s, and these appear to be very much akin to Karinj chanted tales in content, form, and performance (Tipton 1982; email, 20 Oct 2009). Subsequent re-visits in the years 2005-7 suggested to her "that the stories are still told" in those southern and southwestern areas of the Angal language area (Tipton, email, 20 Aug 2009). ${ }^{17}$ A different development is attested for the Mendi region by Theodore Mawe, who was born in the early 1950s near Mendi. He related at the 2006 Chanted Tales Workshop that he still remembered inj (=enj) being told in his childhood days,

17 Asked whether southern Angal narrators indeed "chanted" their stories, Tipton replied (email, 20 Oct 2009) that "the intonation patterns for the entire story were pronounced"; the opening part of the story may have "sounded more like normal prose, but when the [narrators] were working up to a climax, or when the words were repeated a lot, it was more like singing." 
but that the practice has been abandoned since. This storytelling seems to have been associated more with a family setting, that is, with mothers telling tales to their children. Cannibals $(k e o)^{18}$ frequently featured in these stories, just as in the Karinj enj, as we will see. For Wola speakers in the west of the Angal language area, the status quo of the art form could not be ascertained. While sharing much the same corpus of popular folk tales and motifs, it is noteworthy that Sillitoe (email, 1 Dec 2010), over the longue durée of his involvement with the Wola since the 1970s, has never witnessed performances that would qualify as sung or chanted narrating.

\section{Typical plots and cast of characters}

Two very popular basic plots used in enj folk tales make it feasible to speak of two subcategories of stories, even though they are not formally labelled as such and some stories do not fit into this simple scheme.

A typical plot of what I have labelled ascension stories, the first subcategory, centres on the alliance between a young male protagonist and a young woman, a Female Spirit figure from the sky world who assists the young man in becoming a successful and renowned big man. The theme of the boy's transformationmore dominant in Enga and Ipili male puberty rites and stories (Gibbs, chapter 7; Ingemann, chapter 9) - is often attenuated, however. The stories typically culminate in an ascension to the sky whence the young woman hailed.

A second subcategory may be called cannibal or Wan Heyo stories, since they revolve around a cannibalistic male ogre of that name (Wan Heyo) with whom the male or female protagonist must contend. A variation of this cast is the contest between the male protagonist and a Heyo woman, or the rivalry between a Heyo woman and a sky woman for the same male protagonist.

These plots may also be combined. It is interesting to note here that when Somaip (or Karinj) narrators sing stories in the Huli language, as Pita Tapuli (present at the 2006 workshop) commonly does — preferring it to the Karinj language - the tales are similar in form and content to enj rather than Huli bi te proper. That is, his heroes and heroines have to face Wan Heyo rather than his Huli counterpart Baya Horo. This is another indication that in this transitional zone, cultural communalities are stronger than language differences.

There are also other stories that are more entertaining or hilarious than the standard folk tales and may not involve a sky woman or a cannibal at all. One example is the story I titled "Con Man Imakan," a "rubbish" man who tricks a

$18 \mathrm{Keo}$ is clearly cognate to the Karinj term (Wan)Heyo, conforming to a well-attested (if irregular) pattern of phoneme-switching between West and East Angal/Mendi (Rule 1965). 
beautiful woman into marrying him, another the tale of a man who at first has no penis at all and later is endowed, through ancestral assistance, with an organ of unmanageable length.

Narrators may refer to the protagonists of their stories either in a more generic way ("that old woman," "the younger brother," and the like) or assign them names, in which case they choose from a stock of names which are also known to their listeners or self-explanatory. Following conventional usage, these are double names (hyphenated in my transcription) in which the first part usually refers to a place or an ethnic group, in some cases also to a qualifying trait such as 'pretty' (tambuan) or 'skinny' (kulkul), and the second part to the name proper. Place names often refer to real places known to the audience from personal experience or hearsay, but may also refer to imaginary topographical features; a favourite example for the latter is Ipulup, an imaginary border river (in some stories, a lake) to the sky world and hence a name commonly given to sky people or the male protagonist destined to ascend to the sky world. ${ }^{19}$ In ascension stories, the protagonists will often be associated with places or ethnic groups that are further north or higher up altitudinally, such as the groups occupying the Wage headwaters or locales in the high forest. This has to do with a general cosmological opposition between the sky (har) and the ground (su) and with the fact that high altitudes are associated in various ways with the sky world. Female protagonists named after the Lake Kutubu (Ip Kutup) in the far south are either disguised sky women (and thus "goodies") or Heyo women, associated with the cannibal Wan Heyo and expected to fare badly in the story. The reason for this ambivalence will become evident in the discussion of the Somaip social universe below.

Karinj chanted tales are often set in the real world of the local and regional setting, but not in a contemporary world of Tok Pisin schools, markets, aid posts, and the like. Only the imagery may be inspired by the "modern" world: a dance ground or the fabulously rich "waterworld" of Lake Kutubu may be described as "magnificent like a city," and a special light as being as bright as electric light (pawa). In this sense sung stories evoke and celebrate, like Duna stories (Goroka workshop 2006), an idealized pre-colonial past. The real-world setting is often complemented by standard imaginary topographical features and places such as the above-mentioned border river to the sky world (Ipulup), forested mountains, or steep cliffs which have to be climbed to reach the sky world. The intertwining of both real and imaginary places is also done through the use of what Merlan (1995) has called "techniques of verisimilitude": performers may

19 No etymology was volunteered for the name/term Ipulup which, incidentally or not, is the immediate plural imperative of the verb 'to come', but also contains the morpheme ip, which is the word for 'water/river' (additionally, distinguished by tone only, the immediate singular imperative of the verb 'to come'). 
use comparative terms such as "like" or "resembling" to mediate real places and persons with imaginary ones - a valley 'like' (upi) this-or-that valley, a poor old man 'like' (nonpi) so-and-so. ${ }^{20}$

\section{Themes and motifs}

I will first discuss and elaborate on the two identified subcategories of stories and their most conspicuous themes before considering motifs prevalent in chanted tales more generally, across diverse categories and plots.

\section{Skywalkers and the opposition between sky and ground}

Ascension stories focus and elaborate on a fundamental opposition between ground (su) and sky (har), between the human world here on earth and the sky world above. Basically, the narratives depict the terrestrial as a realm of toil and hardship, death and decay, while the celestial is portrayed as a paradise of peace and plenty, immortality and ease. This is a central cosmological orientation not only among the Karinj but also in the wider region (cf. Reithofer 2006:37-63, with further references). We can note a great many standard features and forms to depict this cosmological opposition and the ascension itself, even across individual narrators. The more common ones are discussed here.

In contrast to the mountainous - and hence strenuous - topography of the ground, the sky world is depicted as a 'raised and level place in the clouds' ( $s a$ to or sa piyun to), ${ }^{21}$ flat and comfortable like a platform. Levelness and beauty of the sky world are also conveyed in the circumscriptive term iyu hama-the 'ceremonial ground up there'. The fundamental opposition to this ground here $(s u)$ is expressed bluntly when narrators refer to the sky as su epe-the 'good ground'.22

Celestial abundance and ease are routinely illustrated by the food that awaits the skywalkers: always plentiful and ready-to-eat, it is also distinctly celestial

\footnotetext{
20 Such comparisons are commonly used also by southern Angal (Tipton 1982:18-19) and Wola or West Angal narrators (Sillitoe, pers. comm., 25 April 2008).

$21 S a$ denotes sky or clouds, to a raised platform.

22 It is possible, however, that the latter two phrases originated more recently in the context of Christianization: Sillitoe (pers. comm., 25 April 2008) claims that the term iyu hama was introduced in the Was/Wage valley for heaven, and Tipton (email, 21 Sep 2009) suggests for the phrase su epe ('the good ground') that it was originally coined by missionaries as su epen ('ground heaven'), where epen was a transliteration of heaven. After a while the $n$ was dropped and 'heaven' became, quite fittingly in Christian eyes, 'the good ground'. While Tipton refers to the work of the Christian Union Mission among the Nembi people in the 1970s, such phrases may travel quickly and widely, and it is quite possible that Karinj narrators have adopted here phrases originating in Christian discourse. A careful reading of the early ethnographic literature of the region provides consistent evidence, however, for the pre-Christian (and pre-colonial) existence of a cosmological opposition between sky and ground as outlined in this chapter. How much it has been reinforced or altered in the course of Christianization is another matter.
} 
as it comprises high-altitude pandanus varieties (poetically termed aluweip nem $=$ 'the sun's food') and animals associated with the sky rather than the ground (marsupials and birds). Likewise, pure and tasty drinking water (yuli-ambi) can simply be sucked from a bush vine always dangling within one's reach. In commentaries, this sky water was likened to water taken from a tank or a fridge, that is, to cool, tasty, and readily available water. The outstanding beauty, power, and fertility of the sky world are manifest also in the houses of the sky people (poetically referred to as tikipir anda or oukmar anda) and the prolific growth of ritually and magically significant plants such as ginger (sambi) and bog iris (lep). Most crucial, however, is the celestial abundance of pigs and pearlshells, the two most valuable exchange items in the pre-colonial past. The sky women are identified in many stories as the "mothers" of pigs and pearlshells, that is, as their true owners and ultimate source. The recurring image used here is that of two trees bearing pigs and pearlshells respectively. ${ }^{23}$ The image and the maternal idiom also point to an intimate association indigenously established between wealth and fertility.

In one story, the 'pig tree' (tas isa) and the 'pearlshell tree' (momak isa) are identified with two sisters, one living high up in the north, the other down south on the shore of Lake Kutubu. They eventually ascend to the sky together with a bachelor, leaving behind for the "ground people" only offcuts of pearlshells and a small "rubbish" pig and a female pig for breeding.

This etiological explanation for the paucity and scarcity of these two valuables here on earth was also elaborated by narrator Josep Haip in a commentary. While the identification of (sky) women as the true origin of pigs and pearlshells is not ubiquitous - in some stories, two brothers are identified as "pig tree" and "pearlshell tree" - it does suggest that a notion of the "mythical primordiality of females" (Goldman 1983:96, in reference to the Huli) was current among the Somaip as well. ${ }^{24}$

Another important feature of ascension stories is the alliance between a young man and a sky woman, the Karinj version of the Female Spirit. As indicated above, the liaison may result in an encompassing transformation of the male protagonist that pertains to physical health and attractiveness as much as to moral integrity, power, and wealth. However, this theme of a (celestial) Female Spirit facilitating the transformation of ugly bachelors or 'rubbish little men' (ol teir kang) is not as dominant as it appears to be in the wider region (as discussed in

\footnotetext{
23 The notion of a pearlshell tree was also held by Wola or West Angal speakers (Sillitoe 1979a:302) and beyond the Angal language area (e.g., Meggitt 1965:109; Clark 1991).

24 The theme is certainly also a reflection or recognition of the fact that women — as sisters and wives - open up roads of exchange that are among the most important in any man's personal exchange network. "Women in between" (M. Strathern 1972) open the roads on which pigs, pearlshells, and other valuables travel between exchange partners.
} 
chapter 1 for the Duna, Enga, and Ipili; see also Clark 1999 and A. Strathern and Stewart 2000:80-94 for good overviews). In many a tale, the male hero may be a lonely bachelor, but he is able and strong and handsome from the beginningand a perfect match for the attractive young woman. The emphasis, then, is more often on courtship, so that Karinj tales can be placed half-way between those in the west of the sung-tales region stressing tutelage and guardianship, and those in the east ( $\mathrm{Ku}$ Waru and Hagen) privileging the courtship motif (cf. Rumsey, chapter 11). The following are examples where the transformative aspect is stressed:

- A leprous man and his son live in the forest somewhere to the south; their gardens are planted by a woman who also brings them all kinds of adornments they didn't have before, thus facilitating their transformation into handsome dancers.

- Bodies of lepers become whole and good again upon their ascension to the sky.

- A poor and ugly man is transformed into a handsome young man after being thrown into the black-coloured Ipulup lake (a celestial body of water) and then into a yellow-coloured pool.

It is revealing that narrators who elaborate the courtship scenario commonly emphasize also the asexual character of the relationship, the need to abstain from sex (until after ascension, at least). This theme is obviously linked to bachelor cults as they were practised by neighbouring groups such as the Enga, Ipili, Huli, and Duna (and eventually adopted by the Karinj as well), in which contexts stories about the asexual liaison between spirit brides and bachelors were disseminated widely (chapter 1; see also Wiessner and Tumu 1998:215-44 for a thorough overview and further references).

With regard to the ascension scenarios, various images may be employed, sometimes in combination. The skywalkers may ascend along giant hardwood trees (e.g., hapol brown pines (Podocarpus neriifolius)), growing out of or materializing next to the king post of the house in which the couple is staying, or climb a stone wall or a high mountain, sometimes with the help of vines or the long hardy stalks of a certain grass (tein win) dangling from the summit. The male hero may also grab hold of the sky woman's sedge skirt (unthinkable under normal circumstances) or a marsupial's tail. As the couple ascends to the sky world, the house beneath them frequently bursts into flames and is consumed by fire. In the words of one commentator (Alois Along), the fire functions like a rocket, propelling the two upwards and facilitating their transition from one cosmic realm to the other. 


\section{Wan Heyo cannibal stories and the Somaip social universe}

Karinj folk tales featuring the cannibal ogre Wan Heyo (figures 4-5) are almost invariably linked to the enormous Lake Kutubu (Ip Kutup) in the far south, situated at the extreme periphery of the Somaip social universe. Although few Somaip have ever seen its expanse with their own eyes, the lake inspired narratives about an aquatic land of plenty (called "waterworld" hereafter) that in many ways appears equivalent to the sky world. In these tales, it is the fabulous waterworld of Lake Kutubu which is portrayed as the true origin of all pigs and pearlshells. (The lake lies indeed in the direction from where pearlshells arrived in the region in pre-contact times.) It is evident that we have here another instance of the point raised by A. Strathern and Stewart (2000:71) with regard to Duna imagery: "lakes and sky are often conflated or regarded as mirror images of each other, so that below the lake could be thought of as an inverted equivalent to up in the sky."

Access to this waterworld is jealously guarded by the cannibal Wan Heyo, a nonhuman monster who traps humans like marsupials, breaking their legs to prevent escape before carrying them home in netbags to store and eventually consume them. ${ }^{25}$ Most tales end with a deadly showdown that has Wan Heyo stripped of his magical powers or killed, and his victims rescued/revived. Apart from his cannibalistic appetite, a trait simultaneously signifying his inhuman nature and superhuman strength (Goldman 1998:214-19), Wan Heyo lives very much like other humans. But his privileged access to the waterworld as the source of all wealth enables him to pay bridewealth for many wives and to line up hundreds of pigs for this purpose if need be.

A brief look at one of the stories reveals not only further resemblances between the sky world and the Lake Kutubu waterworld but also, in this case, between a Wan Heyo story and other ascension stories. It is the folk tale I dubbed "The Kutubu Kwin" (The Kubutu queen):

25 There are clearly parallels here — but also structural differences — to Huli tales about a subterranean land of plenty controlled by Baya Horo cannibal ogres (cf. Ballard 1998:71; Goldman 1998:219-20). 


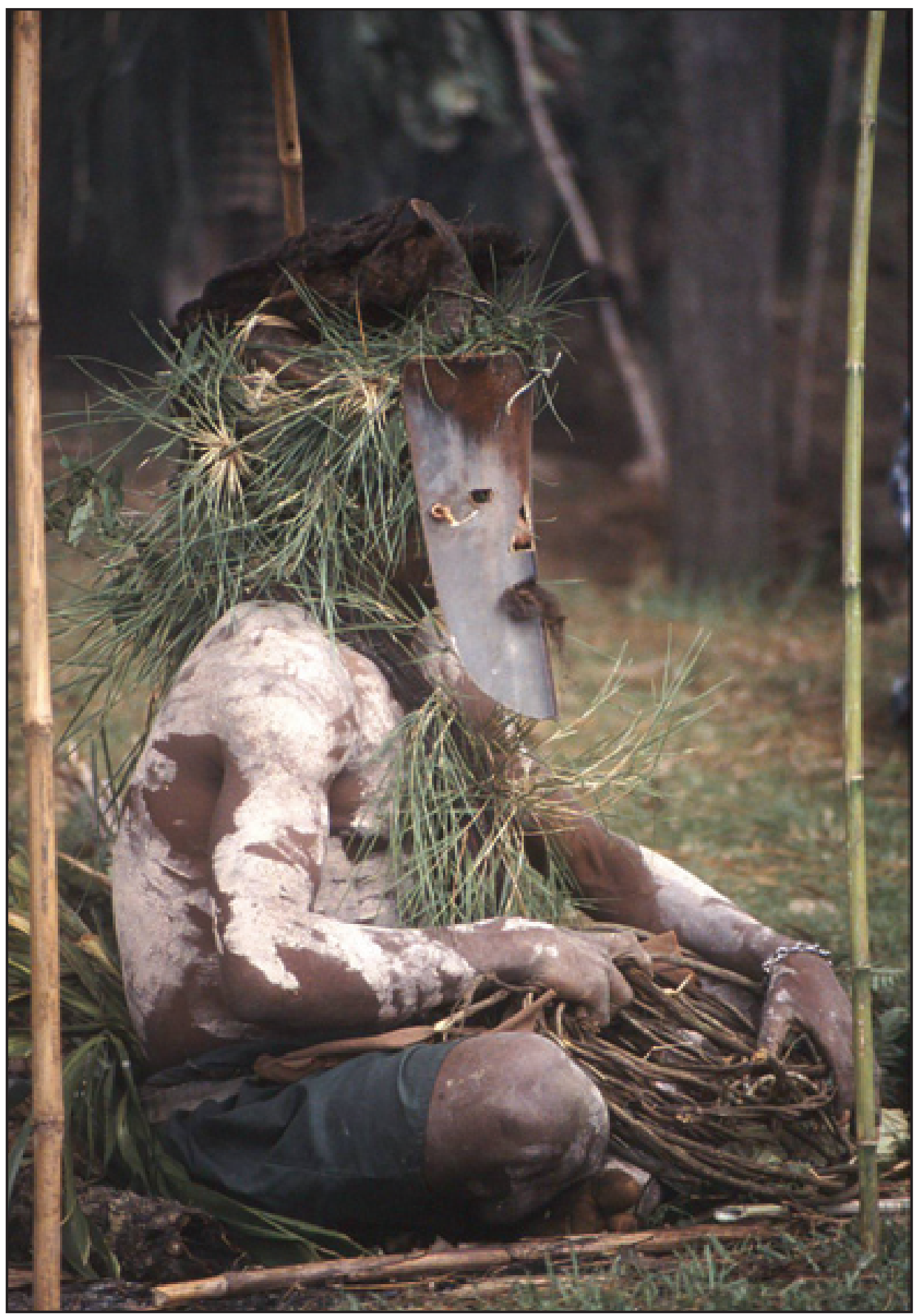

Figure 4. The Wan Heyo cannibal figure as represented in a Karinj performance of a Wan Heyo folk tale at Ipisam, October 2003. Note the coil of rope in his hands for trapping his human victims (photo by author). 


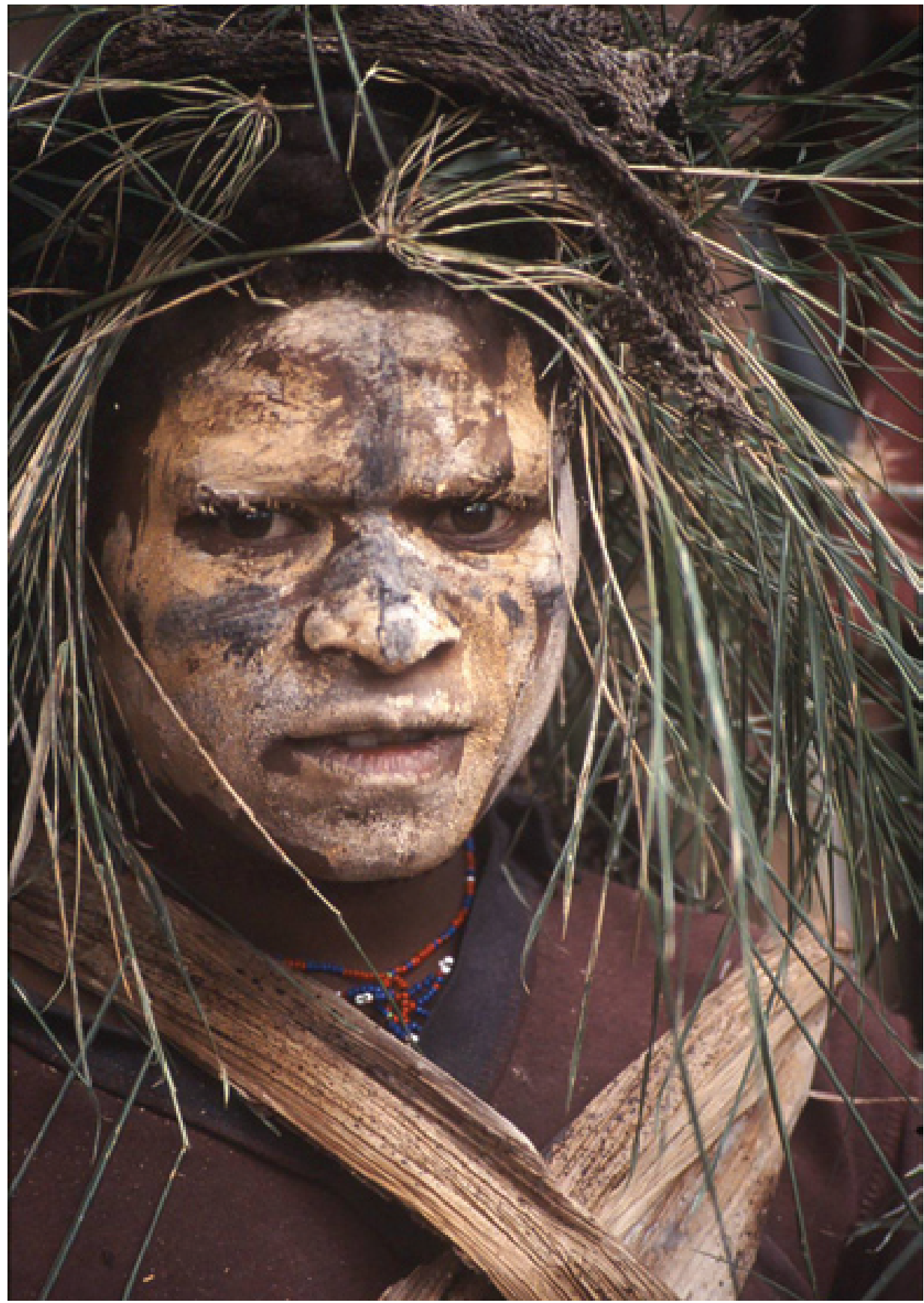

Figure 5. Contravening the aesthetics of self-decoration with the sloppy and profuse application of brown and black paint, and the use of uncomely botanical materials, a Karinj actor captures Wan Heyo's inhuman nature and dangerous/ powerful wildness. Ipisam, October 2003 (photo by author). 
The male hero, having outwitted Wan Heyo and usurped his magical powers, meets the young beautiful (spirit) woman who is the true "queen of the lake" and its riches, and speaks to him from inside a bright light [the Sun?]. Her name is Ipkutup-Wankwank (Lake Kutubu-Wankwank), and she agrees to follow her new protégé, rather in the manner of a wife moving to her husband's place. Lake Kutubu with all its paradisical qualities moves with her, transforming the cane grass-dominated natal place of the hero into a "magnificent city." The spirit woman provides an abundance of everything, looking after the man like a sister, like a mother. The asexual relationship between the two is also the condition of this "dream come true," and when the young hero rapes her despite her protest and warnings, Lake Kutubu vanishes the very same night, together with the "queen," the glorious city and the endless supply of wealth items and fertility. ${ }^{26}$

Here, too, narrator Josep Haip added in an etiological and moralizing comment that the story explained why the Somaip, descendants of the foolish male hero, found themselves in an economically inferior position and why the Lake Kutubu groups fared so well. Their affluence is not a mere mythological contrivance. The forests around the lake are said to abound with wild pigs and cassowaries, and in the past, many valued trade items came from there, most notably pearlshells and the sought-after tigaso decorating oil (termed wambol in Karinj). But the Heyo and Tukup people (ethnographically known as Foi and Fasu) living there and controlling access to this wealth were cast by the Somaip into a role very much akin to Wan Heyo: they were feared as cannibal witches and powerful sorcerers. From a Somaip-centric perspective, the Heyo and Tukup lived at the edge of their social world, at the edge, in fact, of humanness (figure 6). In contrast to 'true/normal humans' (ol heneng), the Heyo and Tukup were said to combine superhuman power and wealth with an almost subhuman physical appearance: "rubbish" decorations, a skinny body and a dull skin riddled with lesions. The Somaip and other "true/normal humans" tapped their riches - with all due precaution - but did not intermingle with them. This maxim of social avoidance was also reinforced by enj folk tales featuring Heyo women, who are often poised in rivalry against sky women as they compete for the attention of the same male bachelor. The bachelor must resist the temptations of the Heyo woman in order to ascend to the sky world, a destination the Heyo woman never attains.

The cannibal ogre Wan Heyo epitomizes the ambiguity of these people at the fringe, their powers as well as their dangers. Various commentators pointed out that the Lake Kutubu people's privileged access to wealth has survived into modern times through the extraction of oil reserves found on their land. If the

26 See chapter 11 for a similar tale from the Hagen area discussed by Rumsey. 
lake was considered the true source of pigs and pearlshells in the pre-contact past, it was now said to be the origin of money, the modern wealth item (Tok Pisin mani $i$ kamap long dispela ples). When whites entered the Somaip universe, there were speculations that they had come from Lake Kutubu, the "true source of power, wealth, and danger."

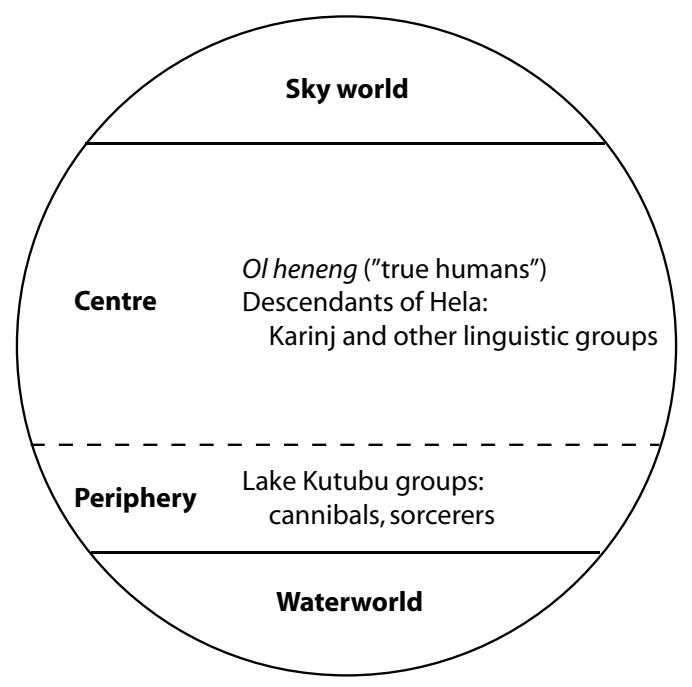

Figure 6. The Somaip cosmos and social universe.

\section{Adherence to a moral order, punishment of wrong-doers}

Karinj folk tales of either category typically convey the message (wrapped up in very good entertainment) that success and social esteem, even immortality, are only for those who adhere to a moral order, as exemplified by the young protagonists who obey their sky-woman friend and do as they are told. It is precisely because the sky people (har kem tenel) adhere strictly to a moral order that their sky world is the place of abundance depicted in the stories. Conversely, those who violate this order or behave grossly antisocial can only expect severe punishment or, if they have already ascended to the sky world, a fall from grace - a fall, alas, that brings about the fundamental imperfections of contemporary life or human existence more generally. ${ }^{27}$ Some stories do end on this pessimistic note (e.g., "The Kutubu Kwin" outlined above), even though the majority of the tales I collected feature a happy ending.

27 Tipton (1982:26-27) suggests for the southern Angal that a moralizing comment on the dire consequences of disobedience is one of three methods of closing an (ancestral) narrative. 


\section{The ambivalence of exogamy}

The rule of exogamy gives rise to the popular motif of courtship between a man and a (spirit) woman from faraway places, a theme present in most Karinj folk tales, and often central in ascension stories (as has already been noted). A. Strathern and Stewart (1997:4) have called this the "romance of exogamy." One recurring image of this romance is the way in which the decorated couple's splendid dance on the ceremonial ground attracts the admiring gaze of all onlookers. The depth of affection is indicated by intense emotions: a sky woman slices her earlobe and lops off a finger joint out of grief for her boyfriend who comes late to the dance and the subsequent ascension to the sky. In other stories, the same inflictions are attributed to brides who have to leave their natal place and people and must go with their husband to a new area and new kinsfolk, thus putting the emphasis on the darker side of exogamy (from a bride's perspective): the general rule of taking up residence with the husband's group. The sadness may be exacerbated by the fact of a more or less forced marriage with Wan Heyo, the trickster cannibal. In the folk tale "The Kutubu Kwin" outlined above, the bride's sadness is projected on to Lake Kutubu itself. Its grief for having to leave its place and follow its "queen" is expressed by heavy rain setting in - as if the sky, too, wept in grief.

Some stories present a burlesque twist of this theme; in the story of the "Man with the Long Penis," it is the cut-off penis which "goes on a journey" and visits women in a far-away place.

\section{Dance and pig-kill}

The popular themes of dance and the pig-kill, not restricted to folk tales, are a favourite ingredient because they enhance the effect of entertainment and evoke memories and fantasies that are likely to make the audience "feel happy." Performers use a number of stock features and images to portray the scenarios as outstanding:

- The dance ground is nice and beautiful like a "city."

- The dancing sky woman is flanked by admiring men like the $o p$ tree by its branches.

- The hero butchers his pig(s) first and fastest, and generously distributes to everyone, so that no one is wanting and everybody praises his name. It is interesting to note here that although pig-kills are collective affairs, the focus is very much on individual participants and the internal competition that exists between them. While this focus is related to the narrative "need" of foregrounding individual protagonists, the tension between group cooperation and internal rivalry is also noted in ethnographic accounts (e.g., Sillitoe 1979a; Lederman 1986a). 
- The butchering of pigs is often done with special magical knives (olsomp ne, mur hari, hari wano) provided by sky people or deftly wielded by the cannibal-sorcerer Wan Heyo. This motif serves to reinforce the lightness and ease of celestial existence as opposed to the hard work of human life on earth. It also contains etiological and moral aspects, as the magical dissection of pigs is often presented as an ability lost to normal humans through some protagonist's immoral, foolish act.

- When the heroes make their appearance on the dance ground, people move aside respectfully and remove obstacles and faeces from their path.

\section{Travelling}

Travelling is ubiquitous in folk tales. There are many reasons for going on a journey: the wish to participate in a dance staged in a far-away place, to visit a girlfriend, to visit the sister who has married someplace else. Standard motifs used by enj performers in this context include the collection and preparation of all kinds of steam-cooked food to carry along or the work that goes into a truly impressive decoration before setting out.

\section{Disguise and deception}

The popular themes of disguise and deception are not restricted to enj folk tales. In ascension stories, a sky woman will often disguise herself as an old, ugly woman or turn into all kinds of disgusting things in the hands of the male hero before revealing her true nature. In cannibal stories, the fearful Wan Heyo may give himself the appearance of a poor and weak man who does not even defend himself when attacked. The themes are played out not only with personae; in one story, for instance, the protagonist urges his mother to bake a seemingly intact taro corm which he had previously hollowed out and filled with ashes.

\section{Lines, melody, and pitch}

Karinj enj are divided into non-metrical lines of varying length, but with a very regular melodic shape. Lines are clearly identifiable on melodic grounds, but also by line-final vocables such as e, la e, la, la o, la la o, or formulae such as inji ('it's been told'). Lines are grouped into melodic units or cycles that have relatively fixed pitch contours, but may vary according to the performer. It seems that each melodic unit comprises a scene or episode of a story and typically ends in meta-narrational locutions that also exhort the audience to respond with a melodic 'oh yes!' (ehe). Two examples follow $(\mathrm{A}=$ Audience $):^{28}$

\footnotetext{
28 A note on the transcription of Karinj (Aklal Heneng) texts: As no language manual or grammar exists for Aklal Heneng, I have worked out, together with Somaip friends, a phonetic system of spelling that lacks the refinement of professional linguistics, but worked well enough for the Somaip themselves. To facilitate their skills in reading their own language, I have more or less limited the system to those characters that are also used in Tok Pisin, the lingua franca with which literate Somaip are most familiar.
} 
1. ... gup lo peyo o. [A:] Ehe!

2. ... gup inja lo pereyo. [A:] Ehe!
... like this I'm telling you. [A:] Oh yes!

... like this it's told and I sit (here) telling you. [A:]

Oh yes!

Ruth Tipton relates from her research in the Nembi and Nipa areas in the 1970s that southern Angal speakers "expected the audience to respond with a grunt. It was one syllable only, and came out like a nasalized grunt. It had no vowels. If the listeners did not respond, the speaker would repeat the lines until he or she got the appropriate audience response" (Tipton, email, 20 Aug 2009).

Accomplished performers command different melodies and may employ them consecutively within the same story in order to enhance their listeners' interest or attention, especially if the performance lasts for hours. Josep Haip, for instance, uses three different melodies, and in the accompanying audio sample (online item 16) _ an extract from his performance at the 2006 Goroka workshop - one can hear such a change in melody at 0:29 into the recording (corresponding to 3:43 of his ten-minute performance). As ethnomusicologist Don Niles noted (email, 23 Feb 2011), one can hear a melodically rather unclear line before Haip shifts to a new, higher range of singing. The new melody exhibits a strict alternation of phrase endings: While all lines end on the meta-narrational formula inji ('it's been told'), Haip ends the two syllables on one pitch in one phrase, and on a pitch a step higher in the other. This strict alternation of different phrase ending pitches is very distinctive and might be seen as having some sort of structural similarity to Hagen performances, where a continually repeated melody is divided into two half-melodies, with many of the notes of one half-melody being separated by a step from the other half-melody (see also Niles, chapter 12). The audio sample also features extended melodic phrases (using the formula gup inja lo pereyo) with which Haip ends larger sections of his story and invites the audience to respond with an affirmation of their interest (ehe). The phrases appear at 0:28, 1:08, and 2:07 into the recording; the response is rather timid at the final instance and missing at the second one, but this is due to the predominantly non-Karinj audience. The audience picked up quickly on Haip's prompts, however, and performed much better during the remainder of the narrative.

\section{Textual parallelism}

The language of enj storytelling is clearly systematically repetitive, as Rumsey (2005:49) has demonstrated for the Ku Waru tom yaya kange and as is probably the case for most if not all genres of sung stories, in Papua New Guinea and elsewhere. Repetition in Karinj enj does not, however, attain the high density it has in $\mathrm{Ku}$ Waru (cf. ibid.). Its most typical form is textual parallelism, that is, two or even three or more successive lines which remain the same except for the substitution of one or a few words. The first example is a motif often used to 
highlight the sense of awe that the splendidly decorated protagonist arouses as he makes his appearance on the ceremonial ground; the gathered people hurry to remove all things dirty and filthy from his path:

1. Ten konwi saim umu tas ii hama-on The women [covered up] the pigs' faeces on the pirisa la dance ground,

2. ol konwi saim san ii hama-on pirisa the men [covered up] the dogs' faeces on the dance la ground,

3. nonak mari umu nonak ii hama-on the mothers [covered up] the children's faeces on the pirisa la dance ground.

The motif illustrates nicely the cultural associations made between women, children, and pigs on the one hand, and men and dogs (used for hunting), on the other. The second example of textual parallelism demonstrates various possibilities for referring to other groups of their social universe in the context of a pig-kill. In accordance with a standard theme, the protagonist manages to distribute first raw strips of pork (poke) and subsequently steam-cooked pork to all attending visitors faster than any of the other hosts:

1. Kulwap nak hal kalisa la

2. iyu Ipilpap nak hal kalisa la e

3. inyu Hond Moint nak hal kalisa la e

4. Karinj Hak nak hal kalisa la e
He gave [poke] to the men from Kulwap [a place in the Enga-speaking north], gave to the Ipili men from up there, gave to the Mendi Lake [Lake Egari] men from down there,

gave to the Karinj men with their white cockatoo headdresses [Huli from Margarima].

Having quickly cut up the cooked pork shortly thereafter, he distributes the pieces:

5. Ank-Lirili nak hal pe

6. Pipi-Lerela nak hal pe

7. Ssei Tandak-Marela nak hal pe

8. Hond Moint nak hal pe

9. Karinj Pol nak hal pe
... to those men from the Pandanus-Aplenty place, to those men from the Frosty place, to those men from the Hailstorm place, to the Mendi Lake men, and to the Karinj men with their white cockatoo headdresses [from Margarima].

The stylized circumscriptions in lines 5-7 refer to places like Yumbis, Longaip, and Gereng at the Wage headwaters, where the climate is even more severe than in the Karinj area and where the high-altitude groves of wild pandanus palms (Pandanus brosimos) are said to regularly produce bumper harvests. References to place names or topographical features (lines 1,3, and 8) or to distinct styles of dress and decoration (lines 4 and 9) are another possibility to denote particular social groups. ${ }^{29}$

29 The synonymous terms (Karinj) Hak and (Karinj) Pol refer to a headdress of typical Huli fashion: white cockatoo feathers mounted on some form of wire or springy slivers and pinned to the hair (cf. Sillitoe 1988:320-22). 
Repetition is manifest in other ways as well, as when a certain motif is repeated refrain-like within the same story (in ascension stories, this may be the formula that the earth is a place of decay and death, "where the lindil mushroom grows and decays" and people die) or when certain themes are used again and again across various stories and even story genres (such as enj and clan origin myths classified as arman), as has been noted in the discussion of themes and motifs. Across stories and story genres, repetition is also evident in the use of a stock of standard expressions and attention markers. If, for instance, a narrator begins a line with the words "When an extended spell of fine weather came" (urpoin ipisa tomben), his or her audience will know that something new and decisive is going to happen.

\section{Special vocabulary and imagery}

The art of good storytelling also hinges upon the use of an adequate and wellestablished vocabulary that is different from everyday speech. Most of the expressions or lexemes used are not exclusive to enj but indicative of a "higher" and more poetic style of language that is said to enhance the overall quality and attractiveness of a performance. The special terms do not pertain to any kind of secret language, however, or make borrowings from what is called the "pandanus language," the language people use when they are in the high forest. ${ }^{30}$ Some of the special terms are obviously from an archaic stock or borrowed from neighbouring languages, ${ }^{31}$ others have referents that are themselves things of the past and hence outside everyday language, such as stone axes and the types of decoration associated with them. Knowledge of this special vocabulary is simply a matter of exposure and growing familiarity, so that older children will have no problem sorting them out. Typical examples for special vocabulary and high stylistic lexemes include the following:

- The protagonists of stories are never simply called nak (lad/man) or nong (girl/woman) but hump nak and hump nong, terms that connote physical attractiveness (rendered as smatpela in Tok Pisin) and establish the persons in question as the main characters of the story.

- Likewise, their houses are never simply called anda, but tikipir anda or oukmar anda, if only to make them stand out from other houses and comply with the stylistic prerogatives of enj storytelling. (The words tikipir and oukmar themselves are not really translatable.)

\footnotetext{
30 Out of fear and respect towards forest spirits - and often also ancestral spirits believed to dwell in high forest pools - people staying temporarily in the high forest will replace terms for things or entities typical of human habitation and village life (such as dogs, pigs, wooden tongs, or axes) or typical of the forest (such as possums or cassowaries) with circumscriptions. Possums, for instance, would be referred to as 'the furry ones' (iri hai) or an axe as 'the sharp one' (ne hai).

31 The enj term for 'sun' (aluweip), for instance, is clearly cognate with the Duna praise name for it, alu(lu) wape.
} 
- Neighbouring groups will be referred to by descriptive terms that are also used in other stylized speech genres (cf. examples above).

- There is a whole battery of high stylistic lexemes used for pigs, each referring to a different skin colour or simply to a "huge pig" (cf. Sillitoe 2003:part 3 for Wola pig lexicography).

- Similarly, special lexemes are often used also for adornments and attire more generally as well as for weapons.

If the special vocabulary serves to create some distance between the narrated events and ordinary or unembellished everyday experience, the effect is heightened by a certain imagery in which actions or events are routinely presented. Exaggeration is one technique employed to this effect. Protagonists usually 'jump' (ponge) rather than simply 'walk' from here to there, and on their journeys they always travel on the more comfortable ridge paths (kunk haret) that are also visible from far away rather than on muddy tracks deep in the forest. Some heroes are even spared the walking and move to a distant place in the wink of an eye with the help of magic ginger (sambi). Here the imagery emphasizes ease where the normal human experience is strenuous walking. The ascension to the sky is routinely described as a gracious dance despite the fact that the skywalkers have to climb a vertical rock wall or a towering tree in order to reach the celestial paradise. Other aspects of this imagery have been pointed out in the above discussion of themes and motifs.

\section{The truth of folk tales}

Compared to clan origin myths classified as arman or 'history,' enj folk tales may be downgraded as 'mere stories' (Tok Pisin stori nating), of little value and import beyond the entertainment factor that inheres in their performances. But if viewed in their own right — and the Goroka Chanted Tales Workshop in 2006 provided a platform and many good reasons for doing so-folk tales have other merits that few Somaip would contest. These stories have te (a foundation, basis or root), their message or teaching is true (pi go heneng), Somaip participants asserted at the workshop. Alois Along viewed the stories as a kind of prophetic talk, as carrying a "promise" within them which will eventually come true or bear fruit. This "promise" concerns the basic moral tenet conveyed in almost all stories, especially of the ascension type. Put simply, it says:

If you follow the "law" (a given moral order), you will have a good life!

If you disobey or disrespect the "law," your life will be miserable!

Therefore, do not disrespect (Tok Pisin sakim) the "law"!

Somewhat less encompassing promises or prophecies contained within folk tales have already come true and thus indicate further the truthfulness of these 
stories, as others pointed out. The high stylistic lexeme kusmen mapen (pigs), for instance, is now seen by many as a hidden prophecy of the large "pigs" that have indeed arrived now in the form of cows and horses! Another example is the sky water yuli-ambi, which is one standard image of celestial comfort and ease; white technology in the form of water tanks, electric power, and refrigerators has made it a part of contemporary human life.

Beyond such particular examples, the truthfulness of folk tales is indeed of a very basic and rather unshakeable kind, as these stories reiterate foundational cosmological and social truths. In so far as these truths guide social behaviour between individuals and among groups, it is social practice-between Karinj and Lake Kutubu groups, for instance - which undergirds the wisdom of these truths. The truth of folk tales is also evident for just about everyone (with the possible exclusion of singular big men) because of the near-universal experience that pigs and pearlshells (and nowadays, money) are always short: too few, too small, too wretched. The true owners and sources of these valuables must have disappeared from the face of the earth long ago. Evidence for the truth of the notion that women are the ultimate origin of these wealth items was also found: in the perception that the true basis or source behind all the white-man's wealth and power is also a woman-Queen Elizabeth!

In important respects it was (and still is) Christianity that provided ample evidence for the truthfulness of folk tales and the appropriateness of their moral messages. It is to this relationship that we now turn.

\section{Chanted tales and Christianization}

\section{Interpreting Christianity}

There is today among the Somaip (as among so many other groups in Papua New Guinea) a pervasive rhetoric of a radical break between their ancestral, "pagan" past, on the one hand, and their enlightened Christian present, on the other. With Christian missionization beginning in the mid-1960s, the Somaip have by and large opted for Christianity in its various forms (Methodist, Catholic, Seventh-day Adventist, amongst others) and turned their back on many things of the past, thus reinforcing this break and widening the gap between the past and the present themselves. But there is a counter-rhetoric to this one, and the processes of interpreting and adopting the Christian message also involved substantial efforts to compare Christian and ancestral traditions, and to sound out their compatibility. Narrative traditions constituted one important body of material that was examined in this way, and folk tales featured strongly here. Enj folk tales and a number of origin myths were found to correspond very closely 
with biblical stories and the Christian message, and thus furnished an important link of continuity between past and present (cf. Reithofer 2006:271-91). These findings had the double effect of validating the truths of indigenous myths and folk tales, and facilitating the acceptance of the Christian narratives as truthful and meaningful. The two narrative traditions were interpreted as mutually reinforcing in many ways. ${ }^{32}$

The category of ascension stories was especially critical here. Somaip friends made this clear to me on several occasions, one of them is still very vivid in my mind. After the memorable performance of one such tale by Josep Haip, the male audience related that when they were told the biblical stories, they perceived them as 'one' (pombor) with their own stories. The parallels were found particularly striking with ascension stories which, according to the men, emphasize the correlation between morality and a good life, and reiterate the point that only a few will ever ascend to the sky, that is, attain a good life. The same message is felt to be expounded in Christian teachings and biblical stories, as a summarized account of their statements makes clear (Reithofer 2006:272):

We Christians have commandments $(l o)$. If we follow them, we will go to heaven and have a good life. If we don't, we won't go to heaven and won't have a good life. Who of us will go to heaven will become apparent only at the end. In any case, those lucky ones will only be a few, while the majority does not ascend to heaven. We can see today, as Christians, that our ancestors too were trying to find God and the way to heaven. It's all too apparent in the stories they told and handed on to us. (29 June 2000)

We can note the following interesting points:

- While some laws/commandments are acknowledged to have changed with Christian teachings, the underlying principle has remained constant: to attain a good life, a moral order has to be upheld and adhered to. The bestknown biblical narrative encoding this principle is the fall of Adam and Eve, as Somaip Christians have pointed out to me: The primordial parents' disobedience vis-à-vis God's established order introduced death and immoral behaviour into the world.

- The autochthonous notion of a sky world is blended with the Christian one of heaven, a process that leaves neither notion unaffected (see below).

- A temporal shift is indicated: Whereas adherence to the ancestrally devised moral order was supposed to translate into a good life in the here and now,

32 It is quite likely that some appropriate contemporary editing of indigenous stories was carried out which furthered the perception and representation of mutually reinforcing narratives, as Sillitoe (pers. comm., 25 April 2008) pointed out to me. A reliable assessment of these processes of rapprochement is difficult, however, and would necessitate a database of stories from the early years of missionization. 
the Christian worldview presupposes a gratification retardant: the chosen few will be revealed only at the end - and perhaps only in what Western tradition calls the afterlife.

- The statements indicate a perception of the Christian religion very much in terms of rules and interdictions.

- They also indicate an interest in vindicating the ancestors as some kind of "anonymous" Christians, if I may borrow this term from Christian theology (Karl Rahner).

The celibacy of Catholic missionaries (priests, clerical brothers and sisters)working in the Angal language area since 1958-reinforced the perception that Christian teachings and ancestral wisdom shared fundamental truths. As noted earlier, one typical feature of ascension narratives is the emphasis on sexual restraint on the part of the male protagonist. According to catechist Alois Along, Catholic missionaries were perceived to follow the example of the mythical skywalkers as they sacrificed themselves and forwent marriage for the sake of a greater good-heaven.

Ascension stories with their popular and standardized depictions of the sky world clearly influenced the Somaip interpretation and imagination of the Christian heaven (heven, har kem). The imagery used in various (Catholic) church songs combines indigenous and biblical/Christian elements: heaven is paraphrased as heven hama or 'heavenly ceremonial ground', an image associated with levelness (and, hence, effortlessness, comfort, and ease), decorative beauty, and centrality; as 'Jerusalem' or 'God's heavenly city' (Goden heven siti), which is said to be huge and connotes a world of plenty, modernity, and richness - just as the "city" of the Lake Kutubu waterworld. According to one hymn, 'water of life' (ip laip) is flowing everywhere in God's house (heaven), an image that was explicitly linked to the sky water yuli-ambi. The image establishes God as the source and provider of good water, the quintessential element of all growth, fertility, and indeed life itself.

The Christian notion of angels, too, resonates with a recurrent feature of enj folk tales: the messenger bird (ek pip) $)^{33}$ which brings important news to isolated or ignorant protagonists. This is also an important function of angels in biblical stories, as Somaip Christians have been quick to notice. In some church skits, men played the role of a pip messenger bird to convey a divine message to humans, thus fusing the notion of a messenger bird with that of angels.

Much more importantly, however, ascension stories with their nostalgic depictions of a limitless and abundant sky world have also facilitated among the Somaip a millennial interpretation of the changes they witnessed and shaped, resisted

33 Alternative terms are ek piauwi and ek pipol. All terms contain the morpheme pi for 'word/talk/language'. 
and reinforced over the last fifty years or so. To many Somaip who have been to Mendi or Mount Hagen, modern town life appeared to closely approximate the unlimited and carefree life in the mythical sky world. As one Seventh-day Adventist put it: "When the Europeans came, we thought that we had gone to the sky at last!" It is difficult to overestimate the ramifications of this interpretation, which still has a strong currency among contemporary Somaip and reached a peak just prior to the turn of the millennium (Reithofer 2006:310-30). With ascension stories in mind, it was easy to read the Christian heaven as a code or vision of a radically different and better world to come.

Of course, the sung stories are themselves only part of a wider context facilitating this millennial reading of their recent history; elsewhere I have discussed other important factors such as a basically "entropic" worldview, indigenous notions of apocalyptic events believed to terminate one earth cycle and inaugurating a new one, and the various speculations about the true origin and nature of the white people, who were widely associated with the sky world (Reithofer 2006:49-61, 224-38).

\section{Reinterpreting chanted tales}

The comparative endeavour stimulated by missionization has established a basic compatibility between indigenous folk tales (and other narratives) and Christian teachings. This perception is apparently shared by the Christian churches as well, since chanted tales have not been-like so many other traditional practicestabooed for baptized Christians. Somaip participants at the 2006 Goroka workshop even viewed their chanted tales as a part of the biblical Good News (Tok Pisin olsem hap gut nius). At the least, they can give support and strengthen the biblical message. The men considered it appropriate, therefore, that in some areas Bible readings were occasionally delivered in the melodic recitation style of enj performances. While I have not witnessed such performances, I have seen other instances of articulating enj stories with the Christian message, of reinterpreting them in a Christian cast. One particularly noteworthy instance involved a rather typical Wan Heyo story that was enacted as a "drama" at a (Catholic) church feast in the so-called Jubilee Year 2000.

Two brothers live together, one a horticulturalist, the other a hunter. One day the hunter gets himself caught in a trap set up by Wan Heyo. When the other brother finds him but cannot disengage the trap, he leaves him with food and turns himself into a mosquito at a place where young women come to drink water. One of the women swallows the mosquito, becomes pregnant and eventually delivers a baby boy. He grows up and later travels to the abode of Wan Heyo, his brother-in-law, with whom he stays for some time. Having detected the hideout in which the cannibal 
ogre kept his victims for later consumption (their legs broken to prevent escape), the young man, aided by a young woman, succeeds in killing Wan Heyo and setting the prisoners free-his brother included.

After the drama, narrator Josep Haip proceeded to give the audience a Christian reading of the story. (Having been the first local Catholic catechist for many years, Haip was well versed in these matters.) The boy being reborn of that young woman is Jesus. The woman, who conceives without the help or assistance of a man, is St. Mary, the mother of God. Wan Heyo's prisoners are to be interpreted as Christians trapped and immobilized by their own sins. Jesus is the saviour who has come to liberate us from our sins. Wan Heyo, finally, is recast as Satan, who has much power over us humans, but is overcome by the greater powers of Jesus.

The enactment and Haip's subsequent interpretation found general approval among the assembled Christians. The example certainly gives an idea of the extent to which chanted tales and Christian teachings may be merged and presented as mutually illuminating and reinforcing. This is true also for other parts of the Angal language area. Very similar biblical reinterpretations of (much the same) ancestral tales and motifs have been proffered by southern Angal speakers in the 1970s (Tipton 1982:27) and by attendants of a Tok Pisin Bible school in the years 2005-7 (Tipton, email, 20 Aug 2009) — another piece of evidence for the ongoing salience of chanted tales in that region.

\section{Conclusion}

Enj storytelling is a verbal art still alive and enjoyed among Karinj speakers in the northwestern part of the Angal language area (and beyond, as we have noted). This chapter has highlighted - to varying degrees - three dimensions of the significance of this art form and the chanted tales themselves. First and foremost, enj performances are a popular form of entertainment, to make people "feel happy," either in the more private settings of men's and women's houses or in the more public contexts of singsing-events or political campaigns. The entertainment factor critically depends on the performer's skill and ability to captivate his or her audience. Secondly and secondarily, chanted tales have educational potential as a means of transporting moral messages that may be further explicated in exegetical commentaries in certain settings. The key theme here is the need to submit to a given moral and social order and its authorities. Thirdly, enj folk tales are valued as a means to reflect on this world as it is represented, ordered, and experienced, and also, as it could be or could have been. Many stories contain etiological aspects that not only provide explanations for certain facts of human life or the nature of the social world, but also help to understand and come to terms with major changes and new developments. 
This latter dimension of significance is evidenced by the way Somaip people have brought their folk tales into dialogue with important events and changes of their recent history: the arrival of white people, colonial rule, the teachings of missionaries and the subsequent adoption and adaptation of Christianity, the oil drilling in the Lake Kutubu region, modern town life, to name a few. Enj folk tales (in conjunction with other narrative traditions) have provided them a measure of orientation as they faced events and new knowledge that were challenging in many ways, to say the least. Conversely, folk tales were themselves subject to reinterpretation in the light of new developments and new knowledge.

The arguments presented in this chapter hopefully conduce to an appraisal of enj storytelling among Karinj speakers which neither exaggerates nor underestimates its social significance in the recent past and at present. They are still a popular form of entertainment, and more than that. Unfortunately, I cannot make a controlled comparison with the significance of this verbal art, say, fifty years ago. This would perhaps make it easier to speculate on its development in the near future. We have some evidence for the North Mendi area that the art of chanting tales has declined over the last fifty years or so, perhaps to the point of being discontinued altogether. The available evidence for the Karinj area (and the southern Angal area) does not suggest such a course at least in the medium term. There is still a widespread appreciation of these tales and their performances "in style," enough to encourage interested and talented individuals to train and develop their performative skills in accordance with local standards and expectations. Josep Haip, for one, has pinned his hopes on his youngest son Samuel, whom he judges to be not only talented but also interested enough to follow in his footsteps. If the Chanted Tales Project orchestrated by Alan Rumsey and Don Niles and this publication have the effect of stimulating interest as well as pride in this verbal art form, this would be not the least of their accomplishments.

\section{Acknowledgements}

I wish to thank Rena Lederman, Paul Sillitoe, and Ruth Tipton for many helpful comments on earlier versions of the paper. By sharing pertinent data from their own research in various parts of the Angal language area, they made it possible for me to include some comparative notes concerning chanted tales among Angal speakers more generally. Many thanks also to Alan Rumsey and Don Niles for inviting me and three Karinj experts to the 2006 Chanted Tales Workshop in Goroka, a platform for stimulating discussion and memorable performances by narrators from across the Highlands. I am especially grateful to Josep Haip, a resourceful Karinj performer who never grew tired of telling me one of his stories, both in prose (pahame) and 'in style' (mo hain), and to Alois Along for his unwavering support and friendship throughout my fieldwork. I gratefully acknowledge also the invaluable assistance of Henry Palip and Toni Joneli 
in translating recorded stories and clarifying countless idiomatic and cultural particularities. For financial support during my principal research among the Karinj (1998-2000), I acknowledge the Catholic congregation of the Society of the Divine Word (SVD), of which I was a long-time member, and the late Bishop Hermann Raich of the Enga Diocese.

\section{References}

Ballard, Chris. 1994. "The Centre Cannot Hold: Trade Networks and Sacred Geography in the Papua New Guinea Highlands." Archaeology in Oceania 29 (3): 130-48.

. 1998. "The Sun by Night: Huli Moral Topography and Myths of a Time of Darkness." In Fluid Ontologies: Myth, Ritual and Philosophy in the Highlands of Papua New Guinea, edited by Laurence R. Goldman and Chris Ballard, 67-85. Westport: Bergin and Garvey.

Ballard, Chris, and Jeffrey Clark. 1999. "Blurred Boundaries and Transformed Identities: Myth and Ritual in the Southern Highlands of Papua New Guinea." Canberra Anthropology 22 (1): 1-5.

Biersack, Aletta, ed. 1995a. Papuan Borderlands: Huli, Duna, and Ipili Perspectives on the Papua New Guinea Highlands. Ann Arbor: University of Michigan Press.

1995b. "Introduction: The Huli, Duna, and Ipili Peoples Yesterday and Today." In Papuan Borderlands: Huli, Duna, and Ipili Perspectives on the Papua New Guinea Highlands., edited by Aletta Biersack, 1-54. Ann Arbor: University of Michigan Press.

Clark, Jeffrey. 1991. "Pearlshell Symbolism in Highlands Papua New Guinea, with Particular Reference to the Wiru People of Southern Highlands Province." Oceania 61: 309-39.

1999. "Cause and Afek: Primal Women, Bachelor Cults and the Female Spirit.” Canberra Anthropology 22 (1): 6-33.

Crittenden, Robert. 1991. "The Back Door to the Purari." In Like People You See in a Dream: First Contact in Six Papuan Societies, edited by Edward L. Schieffelin and Robert Crittenden, 125-46. Stanford: Stanford University Press.

Frankel, Stephen. 1986. The Huli Response to Illness. Cambridge: Cambridge University Press. 
Goldman, Laurence R. 1983. Talk Never Dies: The Language of Huli Disputes. London: Tavistock Publications.

_. 1998. Child's Play: Myth, Mimesis and Make-believe. Oxford: Berg.

Goldman, Laurence R., and Chris Ballard, eds. 1998. Fluid Ontologies: Myth, Ritual and Philosophy in the Highlands of Papua New Guinea. Westport: Bergin and Garvey.

Gordon, Raymond G., Jr., ed. 2005. Ethnologue: Languages of the World. 15th ed. Dallas: SIL International. Accessed 15 February 2008. Online version: http://www.ethnologue.com/.

Lederman, Rena. 1986a. What Gifts Engender: Social Relations and Politics in Mendi, Highland Papua New Guinea. Cambridge: Cambridge University Press.

- 1986b. "Changing Times in Mendi: Notes towards Writing Highland New Guinea History.” Ethnohistory 33 (1): 1-30.

1990. "Big Men, Large and Small? Towards a Comparative Perspective." Ethnology 29 (1): 3-15.

Mawe, Theodore. 1982. Mendi Culture and Tradition: A Recent Survey. Port Moresby: Prehistory Department, National Museum and Art Gallery.

Meggitt, Mervyn J. 1965. "The Mae Enga of the Western Highlands." In Gods, Ghosts and Men in Melanesia: Some Religions of Australian New Guinea and the New Hebrides, edited by Peter Lawrence and Mervyn J. Meggitt, 105-31. Melbourne: Oxford University Press.

Merlan, Francesca. 1995. "Narrative Genres in the Western Highlands of Papua New Guinea." In SALSA II: Proceedings of the Second Annual Symposium about Language and Society, Austin, edited by Pamela Silberman and Jonathan Loftin, 87-98. Texas Linguistic Forum, 34. Austin: University of Texas.

Nihill, Michael. 1986. "Roads of Presence: Exchange and Social Relatedness in Anganen." PhD dissertation, University of Adelaide.

—. 1996. "Alternating Ontologies: Exchange and Ritual in Anganen History." The Australian Journal of Anthropology 7 (3): 275-98.

- 1999. "Time and the Red Other: Myth, History and the Paradoxes of Power in Anganen." Canberra Anthropology 22 (1): 66-87. 
Reithofer, Hans. 2006. The Python Spirit and the Cross: Becoming Christian in a Highland Community of Papua New Guinea. Göttinger Studien zur Ethnologie, 16. Münster: LIT Verlag.

Rule, Joan. 1965. "A Comparison of Certain Phonemes of the Languages of the Mendi and Nembi Valleys, Southern Highlands, Papua." Anthropological Linguistics 7 (5): 98-105.

Rumsey, Alan. 2005. "Chanted Tales in the New Guinea Highlands of Today: A Comparative Study." In Expressive Genres and Historical Change: Indonesia, Papua New Guinea, and Taiwan, edited by Pamela J. Stewart and Andrew Strathern, 41-81. Anthropology and Cultural History in Asia and the Indo-Pacific. Hants: Ashgate Publishing.

Rumsey, Alan, and James F. Weiner, eds. 2001. Emplaced Myth. Space, Narrative, and Knowledge in Aboriginal Australia and Papua New Guinea. Honolulu: University of Hawai'i Press.

Ryan, D’Arcy. 1961. "Gift Exchange in the Mendi Valley.” PhD dissertation, University of Sydney.

Sillitoe, Paul. 1979a. Give and Take: Exchange in Wola Society. Canberra: Australian National University Press.

\section{7.}

. 1979b. "The Menstruating Tree." Cambridge Anthropology 5 (2): 32-

1988. Made in Niugini: Technology in the Highlands of Papua New Guinea. London: British Museum Publications.

1999. "Beating the Boundaries: Land Tenure and Identity in the Papua New Guinea Highlands." Journal of Anthropological Research 55 (3): 33160.

2002. "Always Been Farmer-foragers? Hunting and Gathering in the Papua New Guinea Highlands.” Anthropological Forum 12 (1): 45-76.

2003. Managing Animals in New Guinea: Preying the Game in the Highlands. Studies in Environmental Anthropology, 7. London: Routledge.

Strathern, Andrew. 1968. "Descent and Alliance in the New Guinea Highlands: Some Problems of Comparison." Proceedings of the Royal Anthropological Institute of Great Britain and Ireland 1968: 37-52. 
. 1994. "Lines of Power." In Migration and Transformations: Regional Perspectives on New Guinea, edited by Andrew Strathern and Gabriele Stürzenhofecker, 231-55. ASAO Monograph, 15. Pittsburgh and London: University of Pittsburgh Press.

Strathern, Andrew, and Pamela J. Stewart. 1997. Ballads as Popular Performance Art in Papua New Guinea and Scotland. Centre for Pacific Studies Discussion Papers Series, 2. Townsville: James Cook University of North Queensland.

- 2000. The Python's Back: Pathways of Comparison between Indonesia and Melanesia. Westport, Connecticut: Bergin and Garvey.

Strathern, Andrew, and Gabriele Stürzenhofecker, eds. 1994. Migration and Transformations: Regional Perspectives on New Guinea. Pittsburgh and London: University of Pittsburgh Press.

Strathern, Marilyn. 1972. Women in Between: Female Roles in a Male World; Mount Hagen, New Guinea. Seminar Studies in Anthropology, 2. London: Seminar Press.

Tipton, Ruth A. 1982. Nembi Procedural and Narrative Discourse. Pacific Linguistics, B 82. Canberra: Australian National University.

Wiessner, Polly, and Akii Tumu. 1998. Historical Vines: Enga Networks of Exchange, Ritual, and Warfare in Papua New Guinea. Smithsonian Series in Ethnographic Inquiry. Bathurst: Crawford House Publishing. 